\title{
Can Anti- $\beta$-amyloid Monoclonal Antibodies Work in Autosomal Dominant Alzheimer Disease?
}

Bruno P. Imbimbo, PhD, Ugo Lucca, MSc, and Mark Watling, MD

Neurol Genet 2021;7:e535. doi:10.1212/NXG.0000000000000535
Correspondence

Dr. Imbimbo

b.imbimbo@chiesi.com

\section{Abstract}

The dominant theory of Alzheimer disease $(\mathrm{AD})$ has been that amyloid- $\beta(\mathrm{A} \beta)$ accumulation in the brain is the initial cause of the degeneration leading to cognitive and functional deficits. Autosomal dominant Alzheimer disease (ADAD), in which pathologic mutations of the amyloid precursor protein $(A P P)$ or presenilins $(P S E N s)$ genes are known to cause abnormalities of $A \beta$ metabolism, should thus offer perhaps the best opportunity to test anti-A $\beta$ drugs. Two long-term preventive studies (Dominantly Inherited Alzheimer Network Trials Unit Adaptive Prevention Trial [DIAN-TU-APT] and Alzheimer Preventive Initiative-ADAD) were set up to evaluate the efficacy of monoclonal anti-A $\beta$ antibodies (solanezumab, gantenerumab, and crenezumab) in carriers of ADAD, but the results of the DIAN-TU-APT study have shown that neither solanezumab nor gantenerumab slowed cognitive decline in 144 subjects with $\mathrm{ADAD}$ followed for 4 years, despite one of the drugs (gantenerumab) significantly affected biomarkers relevant to their intended mechanism of action. Surprisingly, solanezumab significantly accelerated cognitive decline of both asymptomatic and symptomatic subjects. These failures further undermine the $A \beta$ hypothesis and could support the suggestion that $A D A D$ is triggered by accumulation of other APP metabolites, rather than A $\beta$.

From the Department of Research \& Development (B.P.I.), Chiesi Farmaceutici, Parma, Italy; Laboratory of Geriatric Neuropsychiatry (U.L.), Department of Neuroscience, Istituto di Ricerche Farmacologiche Mario Negri IRCCS, Milano, Italy; and CNS \& Pain Department (M.W.), TranScrip Partners, Reading, United Kingdom. 


\section{Glossary}

$\mathrm{AD}=$ Alzheimer disease; ADAD = autosomal dominant AD; AICD = APP intracellular domain API = Alzheimer Preventive Initiative; APP = amyloid precursor protein; APT = Adaptive Prevention Trial; BACE1 $=\beta$-site APP cleaving enzyme- 1 ; DIANTU = Dominantly Inherited Alzheimer Network Trials Unit; IgG = immunoglobulin G; NfL = neurofilament light; OCIAD1 = ovarian carcinoma immunoreactive antigen domain containing 1 ; $\mathrm{OR}=$ odds ratio; $\mathrm{SAD}=$ sporadic $\mathrm{AD}$.

Alzheimer disease $(\mathrm{AD})$ is a chronic neurodegenerative disease with an insidious onset, which usually progresses with increasing rapidity. It accounts for around $70 \%$ of dementia diagnoses. There are 2 forms of $\mathrm{AD}$ : the most common is called sporadic $\mathrm{AD}(\mathrm{SAD})$ because it is not caused by a specific gene, although genetic risk factors have been identified, the most important being APOE, CLU, CR1, and PICALM. ${ }^{1}$ SAD generally appears after age 65 years, with most cases occurring after age 80 years. ${ }^{2}$ It is very common, affecting more than 50 million people worldwide. The other type of $\mathrm{AD}$ is quite rare ( $1 \%-3 \%$ of all $\mathrm{AD}$ cases) and has a genetic cause. It is called dominantly inherited $\mathrm{AD}$, familial $\mathrm{AD}$, or autosomal dominant $\mathrm{AD}(\mathrm{ADAD})$. $\mathrm{ADAD}$ is caused by mutations in the amyloid precursor protein $(A P P)$ or presenilins (PSEN1 and PSEN2) genes that cause abnormalities in $A \beta$ metabolism. ADAD generally has an early onset (as young as age 30 years) but can occur at late ages. ${ }^{3}$ APP is the precursor of amyloid- $\beta(A \beta)$, and presenilin-1 is the protease element of the $\gamma$-secretase enzyme complex responsible for the final release of $A \beta$ from APP. $A D A D$ bears neuropathologic and biomarker features that are similar to those of SAD, but they usually occur at a younger age ${ }^{4}$-it therefore offers a potentially valuable setting in which to test the efficacy of drugs targeting $A \beta$.

\section{Pathophysiology and Anti-A $\beta$ Therapeutic Approaches to AD}

The presence of intracellular neurofibrillary tangles and extracellular plaques in the brain is the histologic hallmark of $\mathrm{AD}$. Plaques are mainly composed of $\mathrm{A} \beta$, a 40-42-amino acid peptide with established roles in the mediation of neuronal homeostasis. Neurofibrillary tangles comprise aggregated hyperphosphorylated tau, a protein normally active in axonal microtubular stabilization. Also recognized as histopathologic markers are microglial dysfunction, astrocytic activation, and neuritic dystrophy. The $\mathrm{A} \beta$ cascade hypothesis of $\mathrm{AD}$ asserts that $A \beta$ accumulation in the brain is the initial pathologic event, starting 15-20 years before the disease presents clinically. The autosomal dominant forms of $\mathrm{AD}$ arise following point mutations of APP and the enzymes involved in its processing (PSEN1 and PSEN2), which lead to altered $A \beta$ production. It is noteworthy that another specific mutation of APP (A673T) is recognized to give protection against $\mathrm{AD}$ in cognitively healthy elderly individuals. ${ }^{5}$ The altered amino acid is close to the $\beta$-site APP cleaving enzyme-1 (BACE1) cleavage site and reduces $A \beta$ production in vitro by $\sim 40 \%$. In late-onset $\mathrm{SAD}$, faulty $\mathrm{A} \beta$ clearance and/or increased BACE1 activity are held responsible for $A \beta$ accumulation. Such accumulation has also been linked to the APOE4 allele, making it the most leading genetic risk factor for SAD. Broad acceptance of the amyloid hypothesis has driven the intensive research efforts of the last 20 years to develop compounds that counter $A \beta$ accumulation-an objective mainly pursued through 2 approaches: either the reduction of $A \beta$ production by inhibition of the enzymes (BACE1 and $\gamma$-secretase) that cleave APP to generate $A \beta$ or the enhancement of $A \beta$ clearance by active or passive immunotherapy. Neither of these approaches has been shown to have therapeutic effects in patients with $\mathrm{AD}$, even in the very early stages. ${ }^{6}$

\section{Prevention Studies in Patients With SAD}

Over the last 10 years, the scientific community has realized that the mild-to-moderate or even early stages of $\mathrm{AD}$ are too late for anti-A $\beta$ drugs to reverse or halt disease progression. About $25 \%$ of subjects enrolled in clinical trials in which $\mathrm{AD}$ diagnosis was based on neuropsychological and clinical testing do not have objective evidence of $A \beta$ brain deposition. ${ }^{7} \mathrm{New}$ $\mathrm{AD}$ diagnostic criteria were proposed to define $\mathrm{AD}$-related dementia based on biomarker evidence of brain amyloidosis, thus enabling the identification of preclinical stages of $\mathrm{AD}$ and allowing studies of earlier pharmacologic intervention. ${ }^{8}$

However, to date, prevention studies with anti-A $\beta$ drugs have failed to show lower rates of cognitive decline in cognitively normal subjects at risk of developing $\mathrm{AD}$ (table 1). These prevention studies tested 2 BACE1 inhibitors (atabecestat and umibecestat), and an active anti- $\mathrm{A} \beta$ vaccine (CAD106) in different, cognitively unimpaired populations. The EARLY study, which studied atabecestat, enrolled 557 cognitively normal subjects at risk of developing $\mathrm{AD}$ because of positive family history of dementia, signs of brain $A \beta$ accumulation, or having an APOE4 gene. The study was initially terminated early because of serious liver enzyme elevationssubsequently, however, it was revealed that the drug had worsened cognitive performance compared with placebo. ${ }^{9}$ Two large studies (Generation 1 and Generation 2) both tested umibecestat (a selective BACE1 inhibitor) and CAD106 (an active $A \beta$ immunotherapy) in 1,626 cognitively normal subjects without evidence of $A \beta$ brain deposition but carrying 2 APOE4 alleles. $^{10}$ In July 2019, the umibecestat arms of the 2 studies were prematurely interrupted because of 
Table 1 Anti-A $\beta$ Prevention Studies Conducted in Sporadic Alzheimer Disease

\begin{tabular}{|c|c|c|c|c|c|c|c|}
\hline Compound & $\begin{array}{l}\text { Main } \\
\text { sponsor }\end{array}$ & $\begin{array}{l}\text { Acronym/ } \\
\text { study code }\end{array}$ & Subject population & $\begin{array}{l}\text { No. of } \\
\text { subjects }\end{array}$ & $\begin{array}{l}\text { Treatment } \\
\text { duration }\end{array}$ & $\begin{array}{l}\text { Primary } \\
\text { outcome } \\
\text { measure }\end{array}$ & $\begin{array}{l}\text { Study } \\
\text { completion/ } \\
\text { interruption/ } \\
\text { start }\end{array}$ \\
\hline Atabecestat & Janssen & $\begin{array}{l}\text { EARLY/ } \\
\text { NCT02569398 }\end{array}$ & $\begin{array}{l}\text { Cognitively normal individuals at risk } \\
\text { of developing Alzheimer disease }\end{array}$ & 557 & $54 \mathrm{mo}$ & PACC & $\begin{array}{l}\text { Interrupted May } \\
2018\end{array}$ \\
\hline $\begin{array}{l}\text { Umibecestat } \\
\text { CAD106 }\end{array}$ & $\begin{array}{l}\text { Amgen } \\
\text { Novartis }\end{array}$ & $\begin{array}{l}\text { Generation } \\
\text { S1/ } \\
\text { NCT02565511 }\end{array}$ & $\begin{array}{l}\text { Cognitively normal individuals with } 2 \\
\text { APOE4 genes }\end{array}$ & 481 & $60 \mathrm{mo}$ & APCC & $\begin{array}{l}\text { Interrupted July } \\
\text { and December } \\
2019\end{array}$ \\
\hline Umibecestat & $\begin{array}{l}\text { Amgen } \\
\text { Novartis }\end{array}$ & $\begin{array}{l}\text { Generation } \\
\text { S2/ } \\
\text { NCT03131453 }\end{array}$ & $\begin{array}{l}\text { Cognitively normal individuals with } 2 \\
\text { APOE4 genes }\end{array}$ & 1,145 & $60 \mathrm{mo}$ & APCC & $\begin{array}{l}\text { Interrupted July } \\
2019\end{array}$ \\
\hline Solanezumab & Eli Lilly & $\begin{array}{l}\text { A4/ } \\
\text { NCT02008357 }\end{array}$ & $\begin{array}{l}\text { Cognitively normal elderly individuals } \\
\text { with brain } A \beta \text { deposition }\end{array}$ & 1,150 & $240 w k$ & PACC & $\begin{array}{l}\text { Planned } \\
\text { completion July } \\
2022\end{array}$ \\
\hline $\begin{array}{l}\text { Lecanemab } \\
\text { (BAN2401) }\end{array}$ & Eisai & AHEAD 3 & $\begin{array}{l}\text { Cognitively normal individuals with } \\
\text { intermediate levels of brain } A \beta \\
\text { deposition }\end{array}$ & 400 & 216 wk & $A \beta-P E T$ & Started in July 2020 \\
\hline $\begin{array}{l}\text { Lecanemab } \\
\text { (BAN2041) }\end{array}$ & Eisai & AHEAD 45 & $\begin{array}{l}\text { Cognitively normal individuals with } \\
\text { elevated levels of brain } A \beta \text { deposition }\end{array}$ & 1,000 & 216 wk & PACC5 & Started in July 2020 \\
\hline
\end{tabular}

Abbreviations: APCC = Alzheimer's Prevention Initiative Composite Cognitive; PACC = Preclinical Alzheimer Cognitive Composite; PACC5 = Preclinical Alzheimer Cognitive Composite, version 5.

From ClinicalTrials.gov (clinicaltrials.gov/). Last accessed: March 27, 2020.

worsening cognitive function, and in December 2019, the CAD106 vaccine arms were also stopped. ${ }^{11}$

This leaves 3 major preventive trials ongoing in $\mathrm{SAD}$. The first is the antiamyloid treatment in asymptomatic $\mathrm{AD}$ (A4) study of solanezumab in cognitively normal elderly subjects with signs of amyloid accumulation. This trial, which started in 2014, is not scheduled to complete until late 2022, reflecting the prolonged follow-up required in this stage of $\mathrm{AD}$ development. Recently, 2 other prevention studies with lecanemab (BAN2041) were launched in cognitively normal individuals with intermediate (AHEAD 3 study) and elevated (AHEAD 45 study) levels of brain $\mathrm{A} \beta$ deposition (table 1).

\section{Prevention Studies in Patients With Autosomal Dominant AD}

In 2008 and 2011, 2 international network of research centers, the Dominantly Inherited Alzheimer Network (DIAN) and the Alzheimer Preventive Initiative (API), were launched to establish international, multicenter registries of individuals with $\mathrm{ADAD}$ and to facilitate recruitment to observational and therapeutic studies on these subjects. The DIAN-TU-APT trial was set up to test solanezumab (a humanized immunoglobulin G1 [IgG1] monoclonal antibody that recognizes soluble monomeric form of $A \beta$ ) and gantenerumab (a fully human IgG1 monoclonal antibody that mainly recognizes fibrillary forms of $A \beta$ ) in presymptomatic subjects with ADAD. The API-ADAD trial was set up to test crenezumab (a fully humanized IgG4 monoclonal antibody selective for oligomeric and fibrillar forms of $A \beta$ ) in cognitively normal subjects with $\mathrm{ADAD}$ (table 2).

\section{The DIAN-TU-Adaptive Prevention Trial}

The DIAN-TU-Adaptive Prevention Trial (APT) trial was a double-blind, placebo-controlled study intended to investigate whether gantenerumab or solanezumab could slow cognitive decline in presymptomatic or mildly symptomatic subjects who carried ADAD genetic mutations (PSEN1, PSEN2, or APP). ${ }^{12}$ The study started in 2012 and followed subjects for an average of around 5 years (maximum 7 years). Subjects were expected to develop symptoms within 15 years of enrollment based on the time of disease onset in their parents or already had mild symptoms of cognitive decline/ memory loss at study entry. The trial was undertaken in Australia, Canada, France, Spain, the United Kingdom, and the United States across 24 sites. Originally, the study was a 2-year biomarker target engagement trial, but was later modified to be a full efficacy study measuring a cognitive primary end point following at least 4 years of treatment. In summer 2017, midway through the trial, the dose of gantenerumab was increased fivefold from 225 to $1,200 \mathrm{mg}$ subcutaneously every 4 weeks, whereas the dose of solanezumab was increased fourfold from 400 to $1,600 \mathrm{mg}$ IV every 4 weeks. The primary outcome measure of efficacy was the DIAN Multivariate Cognitive Endpoint, a composite comprised of the delayed recall score from the International Shopping List Test (episodic memory), the Logical Memory delayed recall score from the Wechsler Memory ScaleRevised (executive functioning), the Digit Symbol Coding test total score from the Wechsler Adult Intelligence ScaleRevised (processing speed), and the MMSE total score (global mental status). These measures were selected because of their advantageous psychometric characteristics, namely 
Table 2 Anti-A $\beta$ Prevention Studies Conducted in Autosomal Dominant Alzheimer Disease

\begin{tabular}{|c|c|c|c|c|c|c|c|}
\hline Compound & $\begin{array}{l}\text { Main } \\
\text { sponsor }\end{array}$ & $\begin{array}{l}\text { Acronym/ } \\
\text { study code }\end{array}$ & Subject population & $\begin{array}{l}\text { No. of } \\
\text { subjects }\end{array}$ & $\begin{array}{l}\text { Treatment } \\
\text { duration }\end{array}$ & $\begin{array}{l}\text { Primary } \\
\text { outcome } \\
\text { measure }\end{array}$ & $\begin{array}{l}\text { Study } \\
\text { completion }\end{array}$ \\
\hline $\begin{array}{l}\text { Gantenerumab } \\
\text { and } \\
\text { solanezumab }\end{array}$ & $\begin{array}{l}\text { Hoffmann- } \\
\text { La Roche } \\
\text { and Eli Lilly }\end{array}$ & $\begin{array}{l}\text { DIAN-TU-APT/ } \\
\text { NCT01760005 }\end{array}$ & $\begin{array}{l}\text { Cognitively normal individuals with } \\
\text { amyloid precursor protein or presenilin- } \\
1 \text { or presenilin-2 Alzheimer-causing } \\
\text { gene mutations }\end{array}$ & 144 & $208 w k$ & $\begin{array}{l}\text { DIAN } \\
\text { Multivariate } \\
\text { Cognitive } \\
\text { Endpoint }\end{array}$ & $\begin{array}{l}\text { Completed } \\
\text { February } \\
2020\end{array}$ \\
\hline Crenezumab & $\begin{array}{l}\text { Genentech } \\
\text { and } \\
\text { Hoffmann- } \\
\text { La Roche }\end{array}$ & $\begin{array}{l}\text { API-ADAD/ } \\
\text { NCT01998841 }\end{array}$ & $\begin{array}{l}\text { Cognitively normal individuals with } \\
\text { presenilin-1 E280A gene mutation }\end{array}$ & 252 & $260 w k$ & $\begin{array}{l}\text { API-ADAD } \\
\text { composite } \\
\text { cognitive } \\
\text { Test }\end{array}$ & $\begin{array}{l}\text { Planned } \\
\text { completion } \\
\text { February } \\
2022\end{array}$ \\
\hline
\end{tabular}

Abbreviations: API = Alzheimer Preventive Initiative; APT = Adaptive Prevention Trial; DIAN-TU = Dominantly Inherited Alzheimer Network Trials Unit. From ClinicalTrials.gov (clinicaltrials.gov/). Last accessed: March 27, 2020.

their reduced ceiling and floor effects, relatively low variability, sensitivity to subtle declines occurring before clinical diagnosis, and face validity as indicators of the cognitive phenotype of $\mathrm{AD}$. The DIAN-TU composite is purported to be sensitive to decline and to produce feasible sample size requirements to detect the appropriate effect sizes. For example, with 60 actively treated mutation carrier subjects and 40 placebo-treated mutation carrier participants, the power to identify a $30 \%$ slowing in disease progression at 4 years would be 0.90 using the $\mathrm{ADAD}$ disease progression model, while permitting participants to continue in the study until the last 1 reaches 4 years. ${ }^{12}$ To enlarge the placebo data set, the trial had included natural history data from 49 mutation carriers enrolled in the DIAN observational study, which is collecting comparable progression data as the DIAN-TU-APT.

Full results of the DIAN-TU study were presented at the Alzheimer's Association International Conference 2020 (July 26-30, Amsterdam). ${ }^{13,14}$ One hundred forty-four mutation carriers were enrolled in the study: 52 on solanezumab, 52 on gantenerumab, and 40 on placebo. Compared with baseline, treatment with solanezumab significantly increased CSF levels of $A \beta 42$ but did not significantly affected brain $A \beta$ load, as determined by Pittsburgh compound B -PET. Surprisingly, the drug significantly increased CSF concentrations of neurofilament light (NfL), a marker of neurodegeneration. Importantly, solanezumab treatment significantly accelerated cognitive deterioration in the $\mathrm{AD}$ mutation carriers compared with placebo (cognitive progression ratio $=1.255$, 95\% confidence interval: 1.136-1.376). ${ }^{13}$ The detrimental effects were visible both in asymptomatic and symptomatic subjects. Compared with baseline, gantenerumab treatment significantly lowered brain amyloid burden and increased CSF A $\beta 42$ levels. The antibody treatment significantly decreased CSF levels of total tau, p-tau181, and NfL, effects considered positive, but which did not translate to a cognitive benefit (cognitive progression ratio $=1.063,95 \%$ confidence interval: $0.949-1.180) .{ }^{14}$ The failure of high doses of gantenerumab to produce cognitive benefit in asymptomatic or symptomatic subjects with $\mathrm{ADAD}$, despite significant effects on central $\mathrm{AD}$ biomarkers, may be ascribed to the late introduction of the substantially higher dose levels, an insufficient observation period (4 years), or to a limited sample size. On the other hand, recent animal work has demonstrated that deficiency of p-tau205 is sufficient to impair memory function in the absence of $A \beta$ pathology, ${ }^{15}$ raising key questions about the contribution of tau phosphorylation to the development of $\mathrm{AD}$. The significant detrimental effects on cognition caused by treatment with high doses of solanezumab could be explain by the high affinity of this antibody for monomeric $A \beta$ that could have physiologic role as opposed to the high affinity of gantenerumab for $A \beta$ aggregates or oligomeric species. On the other hand, looking at the lower $95 \%$ confidence interval of the primary end point of the trial (0.949), we should not expect to see breakthrough positive effects of gantenerumab in these subjects.

\section{The API-ADAD Trial}

The API-ADAD trial started in 2013 and is being conducted in cognitively normal individuals (aged $30-60$ years) living in Antioquia, Colombia, and bearing the PSEN1 E280A mutation that leads to early cerebral $A \beta$ deposition followed at around age 50 years by a progressive decline in cognition and clinical function. ${ }^{16}$ In the API-ADAD trial, 169 PSEN1 mutation carriers are receiving crenezumab (undisclosed dose) or placebo as fortnightly subcutaneous or monthly IV injections for at least 5 years. In addition, 83 unrandomized noncarriers are blindly receiving placebo to protect study participants from knowledge of the presence of the pathogenic mutation. The study is scheduled to complete in early 2022.

\section{Reconsidering the Pathologic Role of Familial AD Mutations}

ADAD is linked to specific mutations of APP and presenilins, whereas no mutations of BACE1 are known to cause $\mathrm{AD}$. Figure provides a schematic illustration of the main metabolic pathway of APP and aminoacidic positions of main APP mutations linked to ADAD. $\alpha$-Secretase cleaves the $\alpha$-site of APP releasing $\mathrm{N}$-terminal fragments $\mathrm{sAPP} \alpha$ and the 


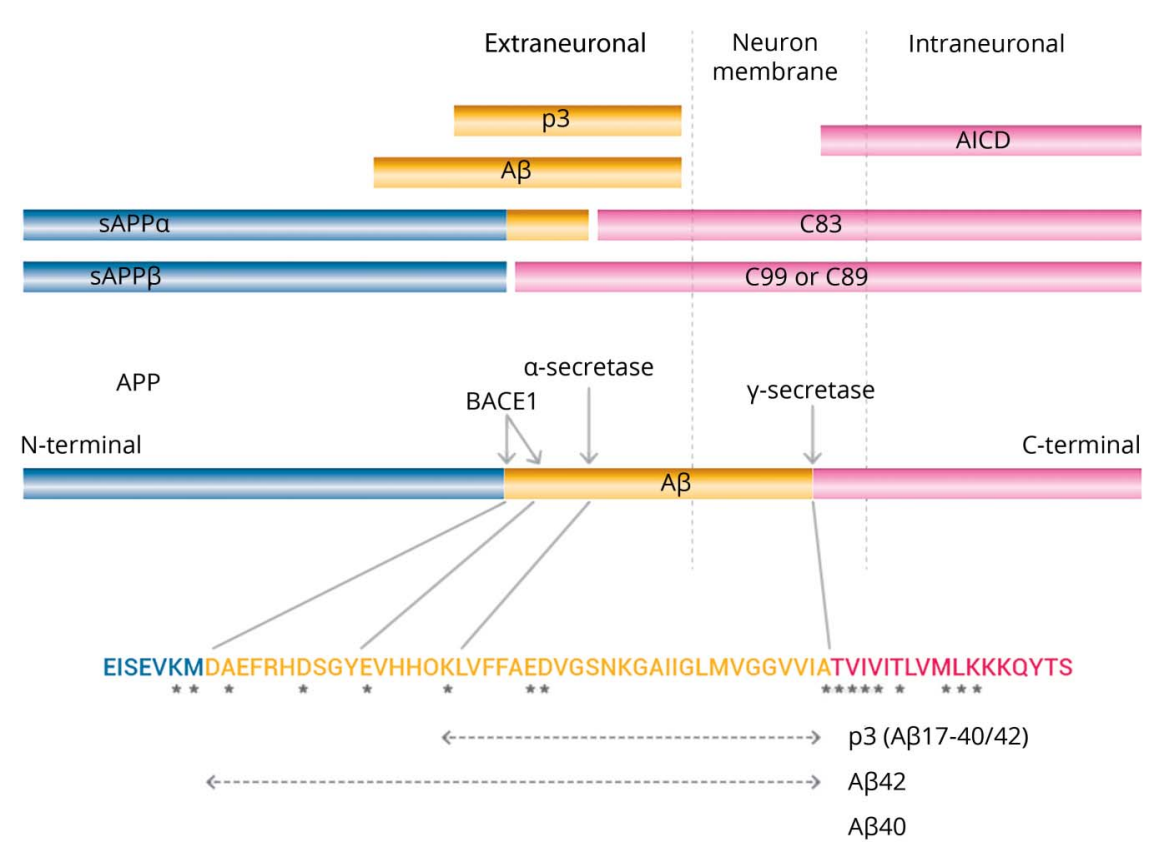

Asterisks indicate pathogenic APP mutations that have been identified in familial $A D$, which cluster near the $\alpha$-secretase, $\beta$-secretase (BACE1), and $\mathrm{y}$-secretase cleavage sites. AD = Alzheimer disease; APP = amyloid precursor protein; BACE1 = $\beta$-site APP cleaving enzyme-1.

C-terminal fragment C83. The $\gamma$-secretase complex then cleaves $\mathrm{C} 83$ releasing $\mathrm{p} 3$ extraneuronally and APP intracellular domain (AICD) intraneuronally. BACE1 cleaves APP at the $\beta$-cleavage site $\left(\operatorname{Met}_{671}-\mathrm{Asp}_{672}\right)$ releasing the $\mathrm{N}$-terminal fragment $\mathrm{sAPP} \beta^{596}$ and the C-terminal fragment C99 $(\mathrm{CTF} \beta) . \operatorname{sAPP} \beta^{596}$ is secreted, whereas C99 is cleaved by the $\gamma$-secretase complex releasing A $\beta$ extraneuronally and AICD intraneuronally. BACE1 is also known to cleave APP at a less well-characterized $\beta^{\prime}$-cleavage site $\left(\mathrm{Tyr}_{681}-\mathrm{Glu}_{682}\right)$. Cleavage of APP at the $\beta^{\prime}$-cleavage site generates $\mathrm{C} 89$ and $\operatorname{sAPP} \beta^{606}$. sAPP $\beta^{606}$ is secreted, and C89 is subsequently cleaved by $\gamma$-secretase to generate truncated $A \beta_{11-40 / 42 .}{ }^{17}$ In the normal physiologic state, $\alpha$-secretase cleaves $\geq 90 \%$ of APP, and the remainder is cleaved by BACE1. The major products in this APP metabolic pathway are thus sAPPa, C83, p3, and AICD (which is rapidly degraded) $-\mathrm{A} \beta$ is normally a minor product. The mutations found in familial $\mathrm{AD}$, especially presenilin mutations, may thus affect the formation and processing of a variety of products. These pathogenic mutations cluster near the $a$-secretase, BACE1, and $\gamma$-secretase cleavage sites (figure) and cause accumulation of APP C-terminal fragments ${ }^{18-20}$; such accumulation has also been found in SAD. ${ }^{21}$ Furthermore, mutations in presenilin, the proteolytic element of the $\gamma$-secretase complex, reduce $\gamma$-secretase activity. $^{22-26}$ These studies indicate that $\mathrm{ADAD}$ mutations can cause complete loss of presenilin-1 function in vivo. Clinically, presenilin mutations are almost always present in a heterozygous state implying that $\gamma$-secretase activity is not completely lost. However, some authors have shown that PSEN1 mutations interfere with $\gamma$-secretase activity in a dominantnegative manner, ${ }^{27}$ suggesting that clinical presenilin mutations may produce familial $\mathrm{AD}$ through a loss-of-function mechanism. The fact that all the hundreds of presenilin familial $\mathrm{AD}$ mutations cause production of a transcript with a full-length open reading frame strongly indicates that the mutant presenilin proteins have a dominant activity that is not simply a haploinsufficiency effect. ${ }^{28}$ The rare cases of homozygosity for PSEN1 familial AD mutations involve alleles that do not have complete loss of $\gamma$-secretase function, thus preserving Notch signaling ${ }^{29}$ that is essential for embryonic development.

A decrease in the catalytic capacity of $\gamma$-secretase, which would lead to an increase in APP C-terminal fragments, facilitates the pathogenesis in familial $\mathrm{AD}^{30,31}$ - thus familial $\mathrm{AD}$ should be considered a disease characterized by a primary accumulation of $\mathrm{C}$-terminal fragments of APP, in addition to an accumulation of $A \beta$. The therapeutic approach of using BACE1 inhibitors would result in accumulation of C83 C-terminal fragment, whereas presenilin dysfunction would result in accumulation of the C99 C-terminal fragment. It is widely recognized that $\mathrm{C} 99$ accumulation induces neuronal toxicity. ${ }^{32}$ Neuropathologic studies in patients with $\mathrm{AD}$ have shown that C99 accumulates in vulnerable neurons, and its levels correlate with the degree of cognitive impairment in patients having $\mathrm{AD}$. In contrast, $\mathrm{A} \beta$ levels are increased in both vulnerable and resistant brain areas. ${ }^{33} \mathrm{C} 99$ is consistently detected much earlier than $A \beta$, suggesting that this APP metabolite could be an early contributor to $\mathrm{AD}$ pathology. ${ }^{34}$ C99 accumulates principally within endolysosomal and autophagic structures, where it is accompanied by C99derived C83 accumulation within the same intracellular organelles. Both these C-terminal fragments of APP dimerize, leading to the generation of higher molecular weight 
species. ${ }^{34}$ In $\mathrm{AD}$ animal models, increases in $\mathrm{C} 99$ provoke the upregulation of cholesterol internalization and its delivery to the endoplasmic reticulum, which in turn result in the loss of lipid homeostasis and the appearance of $\mathrm{AD}$ signatures, such as higher production of longer forms of $A \beta{ }^{35}$ The therapeutic use of $\gamma$-secretase inhibitors mimics the malfunctioning of presenilin in patients with $\mathrm{ADAD}$ with an accumulation of C99. ${ }^{36}$ Overall, these observations would explain why $\gamma$-secretase and BACE1 inhibitors have both produced detrimental effects on cognition ${ }^{6}$ and behavior ${ }^{37}$ in patients with $\mathrm{AD}$. It is interesting to note that the E682K Leuven mutation of $A P P$ appears to drive $A D$ by inhibiting cleavage at the $\beta^{\prime}$-cleavage site of APP. ${ }^{38}$ The inhibition by BACE1 inhibitors of this alternative $\beta^{\prime}$-cleavage site may be another reason why BACE1 inhibitors worsen cognition in clinical trials.

Similarly, monoclonal antibodies specifically directed at $A \beta$ would not work because they do not ameliorate the pathologic accumulation of the C-terminal fragments of APP. ${ }^{39}$ However, because $A \beta$ is included in the $C 99$ fragment, there is the theoretical possibility that some anti-A $\beta$ antibodies may react also with $C 99$. Is should be interesting to verify whether monoclonal antibodies, which have shown some hints of clinical efficacy in $\mathrm{AD}$, like aducanumab and lecanemab (BAN2401), ${ }^{40}$ show cross-reactivity against C99.

\section{Recent Studies Suggest Culprits Other Than $A \beta$ as the Initial Cause of $A D$}

Several recent studies have suggested that an increase in brain $A \beta$ concentration may be not the initial step of the $A D$ process. A neuropathology study in 5,007 subjects has shown that the APOE2/2 allele is significantly associated with an exceptionally low $\mathrm{AD}$ dementia risk odds ratio (OR) compared with both APOE $2 / 3(\mathrm{OR}=0.34)$ and APOE4/4 $(\mathrm{OR}=0.004) .{ }^{41} \mathrm{An}$ other important brain imaging study in 489 subjects showed that APOE\&4 is associated with increased tau-PET uptake in the entorhinal cortex and hippocampus, independent of its link with $A \beta$ accumulation. ${ }^{42} A$ recent case report described a PSEN1 mutation carrier who did not develop mild cognitive impairment until her seventies, 3 decades after the expected age at clinical onset. ${ }^{43}$ The individual had 2 copies of the APOE3 Christchurch (R136S) mutation, high brain amyloid levels, and limited tau and neurodegenerative biomarkers. Although the Christchurch mutation may have protected the PSEN1 carrier from $A \beta$-induced dysfunction through an unidentified as yet mechanism, collectively, these findings indicate that APOE may be implicated in the pathogenesis of $\mathrm{AD}$ through an effect on tau and that this effect is mediated by microglia.

A recent neuropathology study has shown that necroptosis, a programmed form of necrosis characterized by assembly of the necrosome complex composed of phosphorylated proteins (pRIPK1, pRIPK3, and pMLKL), is associated with neuronal loss in the $\mathrm{AD}$ brain. ${ }^{44}$ Another study has shown that a mutation (rs72824905-G) in the PLCG2, the gene encoding for $\mathrm{C} \gamma 2$ (a phospholipase involved in the transmembrane transduction of immune signals), reduces the risk of $\mathrm{AD}^{45}$ Another study has found that the ovary-orientated protein ovarian carcinoma immunoreactive antigen domain containing 1 (OCIAD1) is a neurodegeneration-associated factor for AD. ${ }^{46}$ High levels of OCIAD1 were found in vulnerable brain areas and dystrophic neurites and correlated with disease severity. This study suggests that OCIAD1 contributes to neurodegeneration in $\mathrm{AD}$ by impairing mitochondria function, leading to neuronal vulnerability and synaptic damage. Collectively, these studies suggest that neuronal death in $\mathrm{AD}$ may be linked to $A \beta$-independent mechanisms.

A recent study in 1,289 cognitively normal participants has shown that subjects with untreated diabetes displayed greater tau pathology than both treated patients with diabetes and subjects with normal glycemia and that they progressed to dementia at higher rates than the control group (hazard ratio $=1.602)^{47}$-suggesting that abnormal glucose metabolism may drive $\mathrm{AD}$ pathogenesis. ${ }^{48}$

Finally, a recent study found that DNA from various Grampositive and Gram-negative bacteria results in tau misfolding, especially DNA extracted from certain bacterial species previously detected in the brain, CSF, or oral cavity of patients with $\mathrm{AD}^{49}$ These findings indicate that microbial DNA may play a previously overlooked role in the propagation of tau protein misfolding and $\mathrm{AD}$ pathogenesis. They strengthen the hypothesis that compromised blood-brain and intestinal barriers represent an important source of microbial DNA in the CNS, opening novel opportunities for therapeutic interventions. ${ }^{50}$

Although these studies did not establish whether $A \beta$ is the inciting event of neuronal injury and that multiple mechanisms can occur simultaneously, they point out that the initial cause of $\mathrm{AD}$ may be more complex than was initially thought. Given this, the clinical question is whether anti- $\mathrm{A} \beta$ antibodies still work in patients with the disease? We believe that potent anti$A \beta$ drugs, including anti- $A \beta$ antibodies, should at least slow the initially subtle cognitive decline that can be detected by sophisticated composite cognitive scales in asymptomatic or presymptomatic patients at risk of developing $\mathrm{AD}$ - but this has not been the case up to now, as studies listed in tables 1 and 2 clearly show. It is essentially contradictory that high doses of solanezumab in the DIAN-TU study significantly accelerated cognitive decline in both asymptomatic and symptomatic subjects with $\mathrm{ADAD}$, the prototypical clinical condition to test the $A \beta$ hypothesis of $A D$. This is not the only trial in which worsening of cognition has been seen after anti-A $\beta$ therapy ${ }^{6}$ and such findings should tell us that something is wrong in our understanding of the $\mathrm{AD}$ pathophysiology process.

\section{Conclusions}

The $\mathrm{A} \beta$ hypothesis has dominated $\mathrm{AD}$ research since $1991 .^{51}$ It proposes that brain accumulation of the $A \beta$ peptide triggers 
the formation of tau aggregates, which kill neurons causing neuroinflammation and ultimately leading to dementia. $\mathrm{ADAD}$ is caused by mutations in APP or PSENs genes, both implicated in the generation of the $A \beta$ peptide. Studies from families with $\mathrm{ADAD}$ have been considered critical to supporting the amyloid cascade hypothesis that underpins the current development of amyloid-based disease-modifying therapies in SAD. In the last 5 years, many pharmaceutical companies have abandoned targeting $\mathrm{A} \beta$ to treat $\mathrm{AD}$ as a consequence of a long series of major setbacks in clinical studies, both at early and mild-to-moderate stagesalternative targets such as tau accumulation, neuroinflammation, or microbioma are now being pursued.

A fully successful DIAN-TU study in subjects with $\mathrm{ADAD}$ would have revived the $A \beta$ hypothesis of $A D$ and spurred interest in prevention studies in cognitively normal people without pathologic genetic mutations but at high risk of developing $\mathrm{AD}$ - whether through carriage of a risk-associated allele of the APOE4 gene, parental or family history of $\mathrm{AD}$, or biomarker evidence of brain deposition in the brain. This, however, has not occurred, and the mixed results raise more questions than they answer.

The long list of negative anti- $\mathrm{A} \beta$ trials in $\mathrm{AD},{ }^{6}$ including apparently this last one in the genetic form of the disease, suggests the alternate hypothesis that the observed overproduction of $A \beta$ in $A D$ might simply reflect a form of synaptic plasticity attempting to compensate for neuronal dysfunction. $A \beta$ has important physiologic roles in brain function, including synaptic plasticity, memory formation, and neurogenesis. ${ }^{52}$ The idea that $A \beta$ overexpression is a compensatory mechanism is in line with observations that anti-A $\beta$ drugs like BACE1 and $\gamma$-secretase inhibitors may induce or worsen cognitive performance and psychiatric disturbances in patients with $\mathrm{AD}$ even during the early stages of the disease. ${ }^{9,53}$

Another fascinating hypothesis generated by experimental, genetic, and epidemiologic data is that amyloidogenesis in the $\mathrm{AD}$ brain could be linked to the antimicrobial role of $\mathrm{A} \beta$ and that innate immune-mediated inflammation propagates neurodegeneration. ${ }^{54}$ Amyloid deposition is normally countered by microglial phagocytosis, which clears the amyloid, cellular debris, and dead neurons. In the long term, microglia may switch function and kill neurons as amyloid induced tau aggregation and tangles accumulate. This reactive gliosis and neuroinflammation results in debilitating neural damage and dementia. In 2008, Bertram et al. reported the first gene associated with neuroinflammation in $\mathrm{AD}, \mathrm{CD} 33{ }^{55}$ When highly expressed, CD33 turns the microglial response from protective to pathologic, creating the runaway inflammation that is a distinguishing characteristic of $\mathrm{AD}$. Subsequent research has shown that CD33 inhibits microglial uptake of $\mathrm{A} \beta^{56}$ and that triggering receptor expressed on myeloid cells 2 (TREM2) is working downstream of CD33 to control neuroinflammation. ${ }^{57}$ Studies in a tauopathy mouse model have shown that $A P O E$, the strongest genetic risk factor for $\mathrm{AD}$, regulates neurodegeneration predominantly by modulating microglial activation. ${ }^{58}$ The discovery of these innate immunity genes associated with $\mathrm{AD}$ suggests that the innate immune response could work for decades before symptoms arise in people who carry genetic risk factors for the disease.

The failure to achieve the primary end point of the DIAN-TU study necessitates a reconsideration of the role of APP and $P S E N$ s mutations in familial $\mathrm{AD}$. It may be hypothesized that these mutations trigger $\mathrm{AD}$ pathogenesis through abnormal APP metabolism and accumulation of APP C-terminal fragments rather than $A \beta$ production and $A \beta$ plaque formation. The overproduction of $A \beta$ could be nonspecific, whereas other metabolites of APP (i.e., C99 and C83) could be the real culprits in neuronal death and, as such, should be targeted. Indeed, all attempts to develop $\mathrm{A} \beta$-targeting drugs to treat $\mathrm{AD}$ have ended in failure, and recent findings indicate that the main factor underlying the development and progression of $\mathrm{AD}$ could be tau, not $\mathrm{A} \beta$. Therefore, $\mathrm{AD}$ could be a disorder that is triggered by impairment of APP metabolism and progresses through tau pathology, not $A \beta$. $A \beta$ may just be one character in a complex story that has been too simplistically interpreted for too long. It is now time to reconsider this story from a different perspective to fit all the clues into a coherent and plausible representation.

\section{Study Funding}

No targeted funding reported.

\section{Disclosure}

B.P. Imbimbo is an employee at Chiesi Farmaceutici; he is listed among the inventors of a number of Chiesi Farmaceutici patents of anti-Alzheimer drugs. U. Lucca and M. Watling have no conflict of interest to declare. Go to Neurology.org/ NG for full disclosures.

\section{Publication History}

Received by Neurology: Genetics April 28, 2020. Accepted in final form September 15, 2020.

\section{Appendix Authors}

\begin{tabular}{|c|c|c|}
\hline Name & Location & Contribution \\
\hline $\begin{array}{l}\text { Bruno P. } \\
\text { Imbimbo, } \\
\text { PhD }\end{array}$ & $\begin{array}{l}\text { Chiesi Farmaceutici, Parma, } \\
\text { Italy }\end{array}$ & $\begin{array}{l}\text { Conceptualized the idea of } \\
\text { the manuscript; retrieved } \\
\text { data from the literature; and } \\
\text { drafted the manuscript for } \\
\text { intellectual content }\end{array}$ \\
\hline $\begin{array}{l}\text { Ugo } \\
\text { Lucca, } \\
\text { MSc }\end{array}$ & $\begin{array}{l}\text { Istituto di Ricerche } \\
\text { Farmacologiche Mario } \\
\text { Negri IRCCS, Milan, Italy }\end{array}$ & $\begin{array}{l}\text { Interpreted data from the } \\
\text { literature and revised the } \\
\text { manuscript for intellectual } \\
\text { content }\end{array}$ \\
\hline $\begin{array}{l}\text { Mark } \\
\text { Watling, } \\
\text { MD }\end{array}$ & $\begin{array}{l}\text { TranScrip Partners, } \\
\text { Reading, United Kingdom }\end{array}$ & $\begin{array}{l}\text { Interpreted data from the } \\
\text { literature and revised the } \\
\text { manuscript for intellectual } \\
\text { content }\end{array}$ \\
\hline
\end{tabular}




\section{References}

1. Apostolova LG, Risacher SL, Duran T, et al. Associations of the top 20 Alzheimer disease risk variants with brain amyloidosis. JAMA Neurol 2018;75:328-341.1.

2. Lucca U, Tettamanti M, Tiraboschi P, et al. Incidence of dementia in the oldest-old and its relationship with age: the Monzino 80-plus population-based study. Alzheimers Dement 2020;16:472-481.

3. Day GS, Musiek ES, Roe CM, et al. Phenotypic similarities between late-onset autosomal dominant and sporadic Alzheimer disease: a single-family case-control study. JAMA Neurol 2016;73:1125-1132.

4. Quiroz YT, Sperling RA, Norton DJ, et al. Association between amyloid and tau accumulation in young adults with autosomal dominant Alzheimer disease. JAMA Neurol 2018;75;548-556.

5. Jonsson T, Atwal JK, Steinberg S, et al. A mutation in APP protects against Alzheimer's disease and age-related cognitive decline. Nature 2012;488:96-99.

6. Panza F, Lozupone M, Logroscino G, Imbimbo BP. A critical appraisal of amyloid$\beta$-targeting therapies for Alzheimer disease. Nat Rev Neurol 2019;15:73-88.

7. Selkoe DJ, Hardy J. The amyloid hypothesis of Alzheimer's disease at 25 years. EMBO Mol Med 2016;8:595-608.

8. Sperling RA, Aisen PS, Beckett LA, et al. Toward defining the preclinical stages of Alzheimer's disease: recommendations from the National Institute on Aging-Alzheimer's Association workgroups on diagnostic guidelines for Alzheimer's disease. Alzheimers Dement 2011;7:280-292.

9. Henley D, Raghavan N, Sperling R, Aisen P, Raman R, Romano G. Preliminary results of a trial of atabecestat in preclinical Alzheimer's disease. N Engl J Med 2019;380: 1483-1485.

10. Lopez Lopez C, Tariot PN, Caputo A, et al. The Alzheimer's Prevention Initiative Generation Program: study design of two randomized controlled trials for individuals at risk for clinical onset of Alzheimer's disease. Alzheimers Dement 2019;5:216-227.

11. Graf A, Borowsky B, Tariot P, et al. Alzheimer's Prevention Initiative Generation Program: update and next steps. J Prev Alzheimers Dis 2019;6(suppl 1):S12-S13.

12. Bateman RJ, Benzinger TL, Berry S, et al. The DIAN-TU Next Generation Alzheimer's prevention trial: adaptive design and disease progression model. Alzheimers Dement 2017;13:8-19.

13. Farlow MR. DIAN-TU Prevention Trial: solanezumab in-depth outcomes. Alzheimer's Association International Conference (AAIC) 2020; July 26-30, 2020; Amsterdam. Available at: aaic2020.vfairs.com/en/hall\#topics-tab. Accessed August 9, 2020.

14. Salloway SP. DIAN-TU Prevention Trial: gantenerumab in-depth outcomes. Alzheimer's Association International Conference (AAIC) 2020; July 26-30, 2020; Amsterdam. Available at: aaic2020.vfairs.com/en/hall\#topics-tab. Accessed August 9, 2020 .

15. Ittner A, Asih PR, Tan ARP, et al. Reduction of advanced tau-mediated memory deficits by the MAP kinase p38 $\gamma$. Acta Neuropathol 2020;140:279-294.

16. Rios-Romenets S, Giraldo-Chica M, López H, et al. The value of pre-screening in the Alzheimer's Prevention Initiative (API) Autosomal Dominant Alzheimer's Disease trial. J Prev Alzheimers Dis 2018;5:49-54.

17. Deng $Y$, Wang $Z$, Wang R, et al. Amyloid- $\beta$ protein $(A \beta)$ Glul1 is the major $\beta$-secretase site of $\beta$-site amyloid- $\beta$ precursor protein-cleaving enzyme 1 (BACE1), and shifting the cleavage site to $A \beta$ Asp 1 contributes to Alzheimer pathogenesis. Eur J Neurosci 2013;37:1962-1969.

18. Tesco G, Ginestroni A, Hiltunen M, et al. APP substitutions V715F and L720P alter PS1 conformation and differentially affect $A \beta$ and AICD generation. J Neurochem 2005;95:446-456.

19. Wiley JC, Hudson M, Kanning KC, Schecterson LC, Bothwell M. Familial Alzheimer's disease mutations inhibit $\gamma$-secretase-mediated liberation of $\beta$-amyloid precursor protein carboxy-terminal fragment. J Neurochem 2005;94:1189-1201.

20. Xu TH, Yan Y, Kang Y, Jiang Y, Melcher K, Xu HE. Alzheimer's disease-associated mutations increase amyloid precursor protein resistance to $\gamma$-secretase cleavage and the $A \beta 42 / A \beta 40$ ratio. Cell Discov 2016;2:16026.

21. Pera M, Alcolea D, Sánchez-Valle R, et al. Distinct patterns of APP processing in the CNS in autosomal-dominant and sporadic Alzheimer disease. Acta Neuropathol 2013;125:201-213.

22. Chen $\mathrm{F}, \mathrm{Gu} \mathrm{Y}$, Hasegawa $\mathrm{H}$, et al. Presenilin 1 mutations activate $\gamma_{42}$-secretase but reciprocally inhibit $\varepsilon$-secretase cleavage of amyloid precursor protein (APP) and S3cleavage of notch. J Biol Chem 2002;277:36521-36526.

23. Walker ES, Martinez M, Brunkan AL, Goate A. Presenilin 2 familial Alzheimer's disease mutations result in partial loss of function and dramatic changes in $A \beta 42 / 40$ ratios. J Neurochem 2005;92:294-301.

24. Bentahir M, Nyabi O, Verhamme J, et al. Presenilin clinical mutations can affect $\gamma$-secretase activity by different mechanisms. J Neurochem 2006;96:732-742.

25. Shen J, Kelleher RJ III. The presenilin hypothesis of Alzheimer's disease: evidence for a loss-of-function pathogenic mechanism. Proc Natl Acad Sci USA 2007;104:403-409.

26. Xia D, Watanabe $\mathrm{H}, \mathrm{Wu} \mathrm{B}$, et al. Presenilin-1 knockin mice reveal loss-of-function mechanism for familial Alzheimer's disease. Neuron 2015;85:967-981.

27. Heilig EA, Gutti U, Tai T, et al. Trans-dominant negative effects of pathogenic PSEN1 mutations on $\gamma$-secretase activity and A $\beta$ production. J Neurosci 2013;33:11606-11617.

28. Jayne T, Newman M, Verdile G, et al. Evidence for and against a pathogenic role of reduced $\gamma$-secretase activity in familial Alzheimer's disease. J Alzheimers Dis 2016;52: 781-799.
29. Tambini MD, D'Adamio L. Knock-in rats with homozygous PSEN1 L435F Alzheimer mutation are viable and show selective $\gamma$-secretase activity loss causing low $A \beta 40 / 42$ and high Aß43. J Biol Chem 2020;295:7442-7451.

30. Svedružić ŽM, Popović K, Šendula-Jengić V. Decrease in catalytic capacity of $\gamma$-secretase can facilitate pathogenesis in sporadic and Familial Alzheimer's disease. Mol Cell Neurosci 2015;67:55-65.

31. Kametani F, Hasegawa M. Reconsideration of amyloid hypothesis and tau hypothesis in Alzheimer's disease. Front Neurosci 2018;12:25.

32. Lauritzen I, Pardossi-Piquard R, Bourgeois A, et al. Intraneuronal aggregation of the $\beta$-CTF fragment of APP (C99) induces A $\beta$-independent lysosomal-autophagic pathology. Acta Neuropathol 2016;132:257-276.

33. Pulina MV, Hopkins M, Haroutunian V, Greengard P, Bustos V. C99 selectively accumulates in vulnerable neurons in Alzheimer's disease. Alzheimers Dement 2020 16:273-282.

34. Lauritzen I, Pardossi-Piquard R, Bourgeois A, Bécot A, Checler F. Does intraneuronal accumulation of carboxyl-terminal fragments of the amyloid precursor protein trigger early neurotoxicity in Alzheimer's disease? Curr Alzheimer Res 2019;16:453-457.

35. Montesinos J, Pera M, Larrea D, et al. The Alzheimer's disease-associated C 99 frag ment of APP regulates cellular cholesterol trafficking. EMBO J 2020;39:e103791.

36. Lauritzen I, Bécot A, Bourgeois A, et al. Targeting $\gamma$-secretase triggers the selective enrichment of oligomeric APP-CTFs in brain extracellular vesicles from Alzheimer cell and mouse models. Transl Neurodegener 2019;8:35.

37. Panza F, Lozupone M, Bellomo A, Imbimbo BP. Do anti-amyloid- $\beta$ drugs affect neuropsychiatric status in Alzheimer's disease patients? Ageing Res Rev 2019;55 100948.

38. Zhou L, Brouwers N, Benilova I, et al. Amyloid precursor protein mutation E682K at the alternative $\beta$-secretase cleavage $\beta$ '-site increases $A \beta$ generation. EMBO Mol Med 2011;3:291-302.

39. Dunys J, Valverde A, Checler F. Are N- and C-terminally truncated A $\beta$ species key pathological triggers in Alzheimer's disease? J Biol Chem 2018;293:15419-15428.

40. Panza F, Lozupone M, Seripa D, Imbimbo BP. Amyloid- $\beta$ immunotherapy for Alzheimer's disease: is it now a long shot...? Ann Neurol 2019;85:303-315.

41. Reiman EM, Arboleda-Velasquez JF, Quiroz YT, et al. Exceptionally low likelihood of Alzheimer's dementia in APOE2 homozygotes from a 5,000-person neuropathological study. Nat Commun 2020;11:667.

42. Therriault J, Benedet AL, Pascoal TA, et al. Association of apolipoprotein E $\varepsilon 4$ with medial temporal tau independent of amyloid- $\beta$. JAMA Neurol 2020;77:470-479.

43. Arboleda-Velasquez JF, Lopera F, O'Hare M, et al. Resistance to autosomal dominant Alzheimer's disease in an APOE3 Christchurch homozygote: a case report. Nat Med 2019;25:1680-1683.

44. Koper MJ, Van Schoor E, Ospitalieri S, et al. Necrosome complex detected in granulovacuolar degeneration is associated with neuronal loss in Alzheimer's disease. Acta Neuropathol 2020;139:463-484

45. van der Lee SJ, Conway OJ, Jansen I, et al. A nonsynonymous mutation in PLCG reduces the risk of Alzheimer's disease, dementia with Lewy bodies and frontotemporal dementia, and increases the likelihood of longevity. Acta Neuropathol 2019; 138:237-250

46. Li X, Wang L, Cykowski M, et al. OCIAD1 contributes to neurodegeneration in Alzheimer's disease by inducing mitochondria dysfunction, neuronal vulnerability and synaptic damages. EBioMedicine 2020;51:102569.

47. McIntosh EC, Nation DA; Alzheimer's Disease Neuroimaging Initiative. Importance of treatment status in links between type 2 diabetes and Alzheimer's disease. Diabetes Care 2019;42:972-979.

48. Kuehn BM. In Alzheimer research, glucose metabolism moves to center stage. JAMA 2020;323:297-299.

49. Tetz G, Pinho M, Pritzkow S, Mendez N, Soto C, Tetz V. Bacterial DNA promotes Tau aggregation. Sci Rep 2020;10:2369.

50. Panza F, Lozupone M, Solfrizzi V, Watling M, Imbimbo BP. Time to test antibacterial therapy in Alzheimer's disease. Brain 2019;142:2905-2929.

51. Makin S. The amyloid hypothesis on trial. Nature 2018;559:S4-S7.

52. Gulisano W, Melone M, Ripoli C, et al. Neuromodulatory action of picomolar extracellular $\mathrm{A} \beta 42$ oligomers on presynaptic and postsynaptic mechanisms underlying synaptic function and memory. J Neurosci 2019;39:5986-6000.

53. Egan MF, Kost J, Voss $\mathrm{T}$, et al. Randomized trial of verubecestat for prodroma Alzheimer's disease. N Engl J Med 2019;380:1408-1420.

54. Moir RD, Lathe R, Tanzi RE. The antimicrobial protection hypothesis of Alzheimer's disease. Alzheimers Dement 2018;14:1602-1614.

55. Bertram L, Lange $\mathrm{C}$, Mullin $\mathrm{K}$, et al. Genome-wide association analysis reveals putative Alzheimer's disease susceptibility loci in addition to APOE. Am J Hum Genet 2008;83:623-632.

56. Griciuc A, Serrano-Pozo A, Parrado AR, et al. Alzheimer's disease risk gene CD33 inhibits microglial uptake of amyloid beta. Neuron 2013;78:631-643.

57. Griciuc A, Patel S, Federico AN, et al. TREM2 acts downstream of CD33 in modulating microglial pathology in Alzheimer's disease. Neuron 2019;103:820-835.

58. Shi Y, Manis M, Long J, et al. Microglia drive APOE-dependent neurodegeneration in a tauopathy mouse model. J Exp Med 2019;216:2546-2561. 


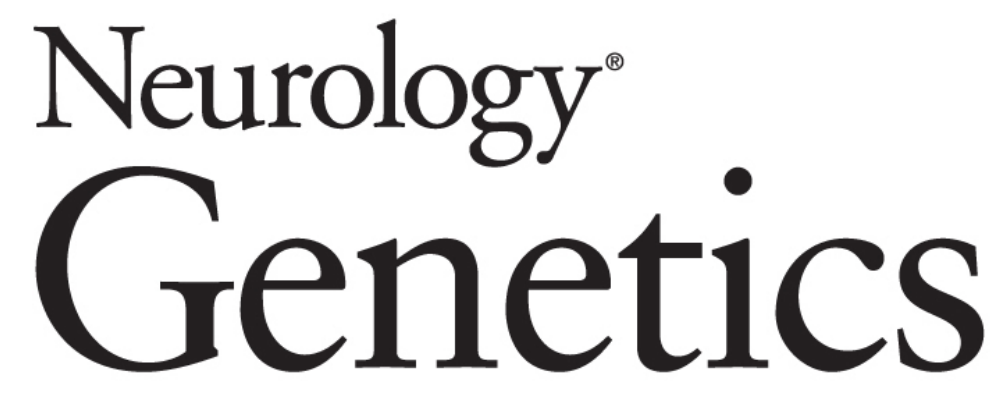

\section{Can Anti- $\beta$-amyloid Monoclonal Antibodies Work in Autosomal Dominant Alzheimer Disease? \\ Bruno P. Imbimbo, Ugo Lucca and Mark Watling \\ Neurol Genet 2021;7; \\ DOI 10.1212/NXG.0000000000000535}

This information is current as of December 17, 2020

$\begin{array}{ll}\begin{array}{l}\text { Updated Information \& } \\ \text { Services }\end{array} & \begin{array}{l}\text { including high resolution figures, can be found at: } \\ \text { http://ng.neurology.org/content/7/1/e535.full.html }\end{array} \\ \text { References } & \begin{array}{l}\text { This article cites } 56 \text { articles, } 10 \text { of which you can access } \\ \text { http://ng.neurology.org/content/7/1/e535.full.html\#\#ref-list }\end{array} \\ \text { Permissions \& Licensing } & \begin{array}{l}\text { Information about reproducing this article in parts (figures, } \\ \text { its entirety can be found online at: } \\ \text { http://ng.neurology.org/misc/about.xhtml\#permissions }\end{array} \\ \text { Reprints } & \begin{array}{l}\text { Information about ordering reprints can be found online: } \\ \text { http://ng.neurology.org/misc/addir.xhtml\#reprintsus }\end{array}\end{array}$

Updated Information \&

References

.

Neurol Genet is an official journal of the American Academy of Neurology. Published since April 2015, it is an open-access, online-only, continuous publication journal. Copyright Copyright ( 2020 The Author(s). Published by Wolters Kluwer Health, Inc. on behalf of the American Academy of Neurology.. All rights reserved. Online ISSN: 2376-7839.

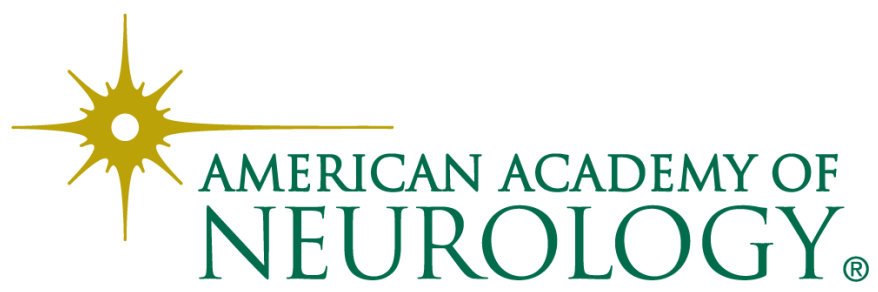

